\title{
Corrigendum: A direct role for Hsp90 in pre-RISC formation in Drosophila
}

Tomohiro Miyoshi, Akiko Takeuchi, Haruhiko Siomi \& Mikiko C Siomi

Nat. Struct. Mol. Biol. 17, 1024-1026 (2010); published online 18 July 2010; corrected after print 25 August 2010

In the version of this article initially published, " 2 '-O-methyl group at the 10 th nucleotide" should have read " 2 '-O-methyl groups at the 9 th and 10th nucleotides." The error has been corrected in the HTML and PDF versions of the article.

\section{Corrigendum: Structural and functional analyses of minimal phosphopeptides targeting the polo-box domain of polo-like kinase 1}

Sang-Moon Yun, Tinoush Moulaei, Dan Lim, Jeong K Bang, Jung-Eun Park, Shilpa R Shenoy, Fa Liu, Young H Kang, Chenzhong Liao, Nak-Kyun Soung, Sunhee Lee, Do-Young Yoon, Yoongho Lim, Dong-Hee Lee, Akira Otaka, Ettore Appella, James B McMahon, Marc C Nicklaus, Terrence R Burke Jr, Michael B Yaffe, Alexander Wlodawer \& Kyung S Lee Nat. Struct. Mol. Biol. 16, 876-882 (2009); published online 13 July 2009; corrected after print 21 September 2010

In the version of this article initially published, two of the numbers shown in Table 1 had the wrong sign. The error has been corrected in the HTML and PDF versions of the article.

\section{Corrigendum: The $\mathrm{C}$ terminus of p53 binds the $\mathrm{N}$-terminal domain of MDM2}

Masha V Poyurovsky, Chen Katz, Oleg Laptenko, Rachel Beckerman, Maria Lokshin, Jinwoo Ahn, In-Ja L Byeon, Ronen Gabizon, Melissa Mattia, Andrew Zupnick, Lewis M Brown, Assaf Friedler \& Carol Prives Nat. Struct. Mol. Biol. 17, 982-989 (2010); corrected online 21 September 2010

In the version of this article initially published, the error bars in Figures 1, 2, 4 and 5 were not defined, and a formatting mistake occurred in Supplementary Figure 1a. The errors have been corrected in the PDF and HTML versions of this article.

\section{Corrigendum: Structure-function analysis of hRPC62 provides insights into} RNA polymerase III transcription initiation

Stéphane Lefèvre, Hélène Dumay-Odelot, Leyla El-Ayoubi, Aidan Budd, Pierre Legrand, Noël Pinaud, Martin Teichmann \& Sébastien Fribourg

Nat. Struct. Mol. Biol. 18, 352-358 (2011); published online 27 February 2011; corrected after print 17 March 2011

In the version of this article initially published, reference 20 was not cited in the main text. The error has been corrected in the HTML and PDF versions of the article.

\section{Erratum: The prospects for designer single-stranded RNA-binding proteins}

Joel P Mackay, Josep Font \& David J Segal

Nat. Struct. Mol. Biol. 18, 256-261 (2011); published online 27 February 2011; corrected after print 17 March 2011

In the version of this article initially published, in several instances "guanidine" should have read "guanine", "uridine" should have read "uracil", and "adenine" should have read adenosine; in two instances; "tetratrispolin" should have read "tristetraprolin"; and Figure 2c,d should have illustrated the structure from PDB record 1M8Y. These errors have been corrected in the HTML and PDF versions of the article. 